Madrygal. Revista de Estudios Gallegos

ISSN: 1138-9664

\title{
Loito na investigación galega ${ }^{1}$
}

Xesús Alonso Montero

Beatus qui legit

O 23 de setembro, cando acababa de cumprir 57 anos, faleceu en Vigo, a súa cidade natal, Victoria Álvarez Ruiz de Ojeda. Licenciada en Filoloxía Hispánica (1984) e profesora de Literatura española (nos últimos anos no Instituto de Mos), era coñecida e admirada - certo que de poucos profesionais- polos seus traballos de investigación literaria, eido no que publicou páxinas escritas con moito rigor intelectual, con obxectividade e con notable pulcritude estilística.

Foi, sobre todo, unha eminente rosalióloga desde 1986, data da súa Memoria de Licenciatura sobre as peculiaridades do galego na obra de Rosalía de Castro. Muller moi discreta, nunca na punta da póla, nin se prodigou en actos públicos nin frecuentou cenáculos que, de seren serios, chufarían as súas meditadas e coidadas investigacións. Sobre capítulos significativos da biografía de Rosalía exhumou documentos decisivos para entendermos o existir daquela voz singular tan reveladora: documentos que foron froito de centos de horas (sic) de indagación (Madrid, Salamanca, Palencia...) e de non poucos millóns de pesetas nunca procedentes das arcas públicas ou das institucións privadas. Os documentos, no labor da investigadora, non só foron descubertos e exhumados por ela senón que foron debidamente contextualizados e interpretados.

Non sería xusto reducir a esta investigadora á condición de rosalióloga. Outros temas das Letras galegas lle deben a súa ollada lúcida, sempre sustentada nunha prodixiosa erudición que lembra a biografía intelectual daquela filóloga arxentina que se chamou María Rosa Lida de Malkiel (1910-1962). Aí están as súas páxinas sobre Curros Enríquez, Lamas Carvajal, Leiras Pulpeiro, Murguía, Eladio Rodríguez González, Eduardo Blanco Amor, Luís Seoane, Fernández del Riego, a Real Academia Galega, o conto popular... Os lectores esixentes agradecen a súa interpretación do Catecismo do labrego, que editou con tanto decoro, ou o roteiro dos personaxes d' $A$ esmorga, que construíu con tanta pericia, e os devotos de Curros gaban as cartas do escritor que ela editou por primeira vez. Tamén sería inxusto non citar os seus minuciosos estudos bibliográficos á cabeza dos cales debe figurar o que lle dedicou a Murguía. Do seu respecto pola Ecdótica é mostra moi elocuente unha ponencia de 1998, aínda inédita, sobre os problemas textuais dos Seis poemas galegos de García Lorca.

Gran lectora de Literatura española, portuguesa, inglesa e francesa (no orixinal), amou os libros de viaxes, as memorias das escritoras, certos tratados de Historia, as boas biografías e as guías literarias das grandes cidades históricas (algunhas das cales visitou (Roma, Florencia, Venecia, Oxford, Atenas, Lisboa, París, Habana...).

Sabia lectora de libros de cociña, coleccionou curiosos textos con menús en lingua galega ao tempo que reunía a mellor colección de ex libris de Galicia, unha das facetas da súa paixón bibliofílica. Filla de pintor ("San Luis"), as artes plásticas estaban entre as súas devocións. Foi unha profesora de ensino medio de palabra 
culta, moi coidada e precisa, e interpretaba os textos literarios desde dentro do seu propio universo e líaos coa prosodia que aplaudirían Rafael Lapesa e María Victoria Moreno.

Foi alumna miña en terceiro curso de Filoloxía Hispánica, ano no que me deslumbrou cun traballo sobre o Diálogo de la lengua de Juan de Valdés. Non tardaría en ser experta en Garcilaso, Góngora, Quevedo e Cervantes, como lembran os alumnos dignos das súas clases tan preparadas. Nos trinta anos que vivimos xuntos (1988-2018) fun un mal alumno dela: dos seus criterios, de certas actitudes ante a vida, dos seus xuízos literarios e da súa vasta cultura.

Quizais para algúns non é axeitado que eu faga esta lembranza e esta gabanza. En calquera caso, non é este artigo unha elexía persoal; é unha breve incursión na personalidade intelectual dunha investigadora literaria que acaba de causar baixa no universo das Letras galegas. Lembranzas máis ou menos semellantes publicaron, nestas datas, entre outros, María Xesús Lama, Dolores Vilavedra, Marilar Aleixandre e Ramón Nicolás, lembranzas nas que, dun xeito ou doutro, poñen o acento no feito de que a obra literaria de Victoria Álvarez non ten tido o recoñecemento condigno, circunstancia -engado eu-á que ela contribuíu non pouco co seu retraemento no mundanal ruído das Letras.

Levo algúns días organizando o inmenso material que constitúe o seu Arquivo Rosaliano, arquivo que, por desexo dela, será ofrecido á Universidade de Santiago. O contacto con tanta bibliografía rara, con tantos inéditos valiosos e con tantos documentos reveladores reforzan en min a idea de que unha gran parte do gremio literario do noso país estaba moi alleo aos traballos e aos días desta calada e teimosa investigadora. $\mathrm{O}$ mesmo me acontece cando me debruzo sobre o material -o inxente material- que durante anos xuntou para redactar a historia da Real Academia Galega, tema da súa tese de doutoramento que non chegou a presentar.

Do que se trata, pois, no presente artigo, é de comezar a reivindicar a voz dunha investigadora literaria, descoñecida ou moi pouco coñecida mesmo entre os colegas. O tempo dirá cales foron, nos estudos literarios galegos, a súa valía, a súa orixinalide e a entidade das súas contribucións. Non é inxusto que eu, precisamente eu, achegue algúns datos e algunhas consideracións para, canto antes, facermos xustiza á sólida biografía da investigadora literaria Victoria Álvarez Ruiz de Ojeda. 